\title{
Rate and Mechanism of Silica Reduction*
}

\section{By Akira ADACHI,** Kazumi OGINO, ${ }^{* *}$ and Shigeta HARA ${ }^{* *}$}

\begin{abstract}
Synopsis
Rate and mechanism of silicon transfer from molten $\mathrm{CaO}-\mathrm{SiO}_{2}-\mathrm{Al}_{2} \mathrm{O}_{3}$ slag to carbon saturated iron were investigated. Effects of stirring of slag phase and the ratio of slag-graphite/slag-metal interfacial areas on the rate of silicon transfer were also studied in the current investigation. In addition, the electrolysis of molten slag was made to know the mechanism of silica reduction. These results showed that there was some difference in the reduction process of silica by carbon dissolved in molten iron and by solid graphite. It was considered that the rate of silica reduction in molten slag was mainly controlled by the diffusion process in slag phase. It may be reasonable to consider that the process of silica reduction proceeds through the following steps; $\mathrm{Si}^{4+} \rightarrow \mathrm{Si}^{2+} \rightarrow \mathrm{Si}$.
\end{abstract}

\section{Introduction}

Many investigations have been made on the process of silica reduction because of its importance, but the reduction mechanism and the rate controlling steps of this process are not well defined yet. From the results obtained by the investigations concerning the rate of silica reduction, it is suggested that the following steps are effective for the rate controlling ; (1) rupture of the Si-O bond, ${ }^{1)}$ (2) diffusion of oxygen from metal to $\mathrm{CO}$ bubble, ${ }^{2}$. (3) reaction at the slag-metal interface, ${ }^{3)}$ and (4) rupture of silicate and diffusion of $\mathrm{O}^{2-}$ and $\mathrm{Si}^{2+}$ ions in slag. ${ }^{4)}$

According to some of the recent reports, it is pointed out that the reaction of silica reduction by carbon saturated iron shows some electrochemical nature. ${ }^{4), 5}$ Standing on the electrochemical viewpoint, some examinations have therefore been made on the mechanism of silica reduction.

\section{Rate of Silicon Transfer from Slag to Metal}

\section{Experimental Procedure}

In order to examine the influence of the stirring speed of slag phase on the rate of silicon transfer from slag to metal, the apparatus shown in Fig. 1(a) was used. In this apparatus, the slag phase was stirred with a graphite rotar (9). The distance between the lower end of the rotar and the slag-metal interface was fixed to be $5.0 \mathrm{~mm}$. Through a sampling hole installed in the center part of the graphite crucible (2), metal samples were taken out with a silica tube of $6 \mathrm{~mm}$ in diameter by suction without penetrating it into slag.

Purified argon gas was used to maintain the furnace atmosphere and the temperature was measured by a $\mathrm{Pt}-\mathrm{Pt} \cdot 13 \% \mathrm{Rh}$ thermocouple. Fluctuation of the temperature during the experimental run was con- trolled within $10^{\circ} \mathrm{C}$. Weight of the metal used for each experiment was $150 \mathrm{~g}$ for carbon saturated iron and $170 \mathrm{~g}$ for copper. Before the experiment, the metal was melted in a graphite crucible to be saturated with carbon and then cast into a graphite mould. Mother alloys thus prepared were used for the experiments.

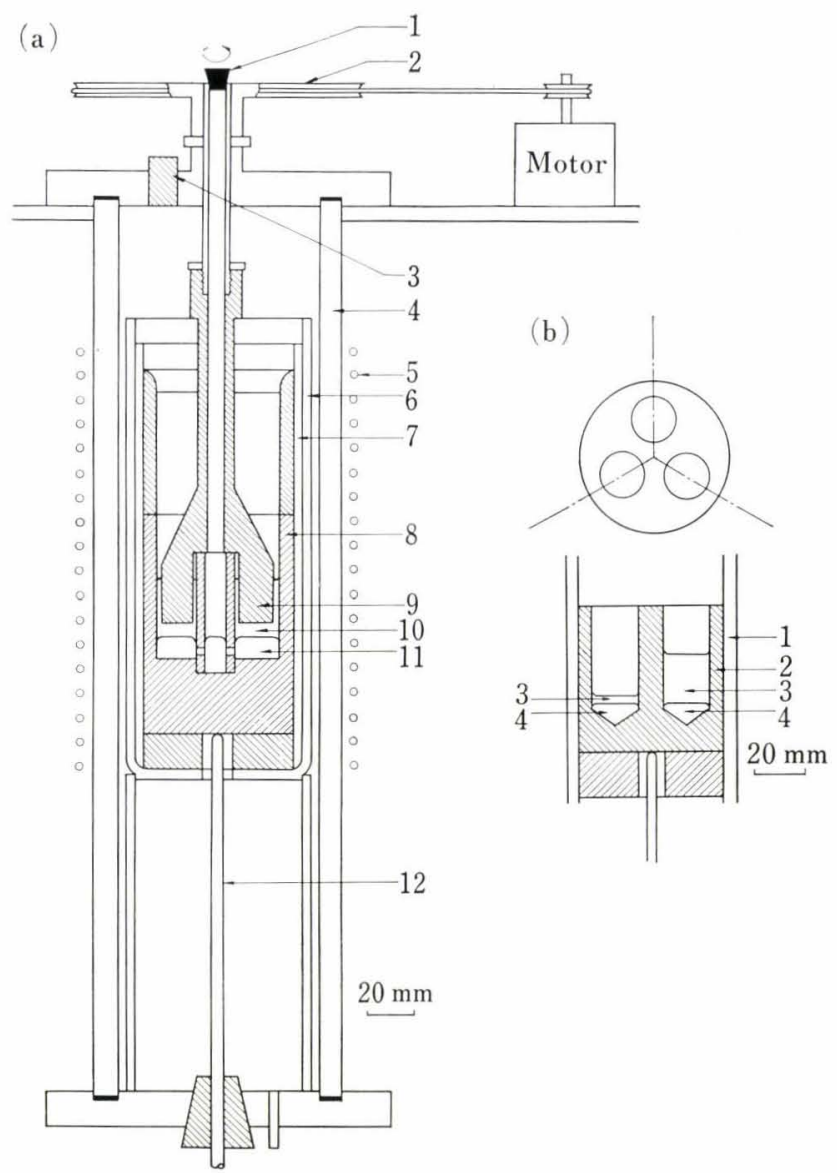

(a) For the examination of the effect of slag-phase stirring

1. Sampling hole 7. Graphite heater

2. Pully 8. Graphite crucible

3. Slag charging-hole 9. Graphite rotating disk

4. Silica tube

5. Induction coil

10. Molten slag

11. Molten metal

6. Alumina outer crucible 12. Thermocouple (Pt-Pt.Rh)

(b) For the examination of the effect of the ratio of slag-graphite/ slag-metal interfacial area

1. Graphite heater

2. Graphite crucible

3. Molten metal

Fig. 1. Furnace arrangement 
Similarly, chemically pure reagents of lime, alumina, and silica were mixed, melted in a graphite crucible, cast into a graphite mould, and then crushed. The pulverized slag of $70 \mathrm{~g}$ was used in each run.

Some physicochemical properties of the slags used in this work are summarised in Table 1. The values listed are used for the analysis of experimental data obtained.

In each experimental run, the metal was heated to the experimental temperature in an induction heating furnace (mercury gap type $35 \mathrm{kVA}$ ) and kept for about $30 \mathrm{~min}$. The slag powder was then charged through the charging hole. After the charged slag was completely fused, the first metal sample was sucked up with a silica tube through the driving tube (see Fig. 1(a)). Experiments were made over the temperature range $1450^{\circ}$ to $1650^{\circ} \mathrm{C}$ and the range of stirring speed 0 to $530 \mathrm{rpm}$.

Two series of stirring tests were carried out; one is for the slag-carbon saturated iron system and the other is for the slag-copper system. A special crucible with three holes was used to measure the effect of the ratio of slag-graphite/slag-metal interfacial areas on the rate of silica reduction (Fig. I(b)). In each experimental run, the metal of $20 \mathrm{~g}$ was heated to $1550^{\circ} \mathrm{C}$, kept at this temperature for $30 \mathrm{~min}$ and then slags of 5,10 , and $15 \mathrm{~g}$, respectively were charged into each hole of the crucible through the slag charging hole. After the charged slag was fused, the crucibles were kept at $1550^{\circ} \mathrm{C}$ for 60,120 , or $180 \mathrm{~min}$ and then they were cooled in the furnace.

\section{Results}

Stirring of the slag phase and the species of the metal phase gave some effects on the apparent reaction rate. However, the concentration of silicon in metal increased proportionally to the reaction time as already observed in the previous study. ${ }^{8)}$

$$
d n_{\mathrm{Si}} / d t=\text { const. }
$$

The relation between the increased concentration of silicon in metal, $\Delta \mathrm{Si}\left(=\mathrm{Si}_{t=t}-\mathrm{Si}_{t=15} \mathrm{~min}\right)$ and the reaction time, $t$, at $1550^{\circ} \mathrm{C}$ is shown in Fig. 2. The ex- perimental results are summarized in Table 2. The rate of silicon transfer from slag to metal increased with increasing temperature and stirring speed of the slag phase.

When a metal contacts with a slag in a graphite crucible, the reaction of silica reduction may proceed by the following two types of reactions (see Fig. 3),

$$
\begin{gathered}
\left(\mathrm{SiO}_{2}\right)+2 \underline{\mathrm{C}}=\underline{\mathrm{Si}}+2 \mathrm{CO}(\mathrm{g}) \\
\left(\mathrm{SiO}_{2}\right)+2 \mathrm{C}(\mathrm{g})=\underline{\mathrm{Si}}+2 \mathrm{CO}(\mathrm{g})
\end{gathered}
$$

Since the solubility of carbon in molten copper is very small, the transfer of silicon from slag to metal for slag-copper system may be mainly accomplished by the reaction (3). The rate of reaction (2) can therefore be estimated from the difference between the results obtained for the slag-copper and the slag-carbon saturated iron systems.

\section{Effect of Stirring}

In case that the rate of reaction is controlled by the rate of diffusion of the reactants, the diffusion flux, $J$, of the reactants, through the reaction surface of rotating disk is given by the following equation. ${ }^{9}$

$$
J=0.62 \nu^{1 / 6} D^{2 / 3} \omega^{1 / 2} C o
$$

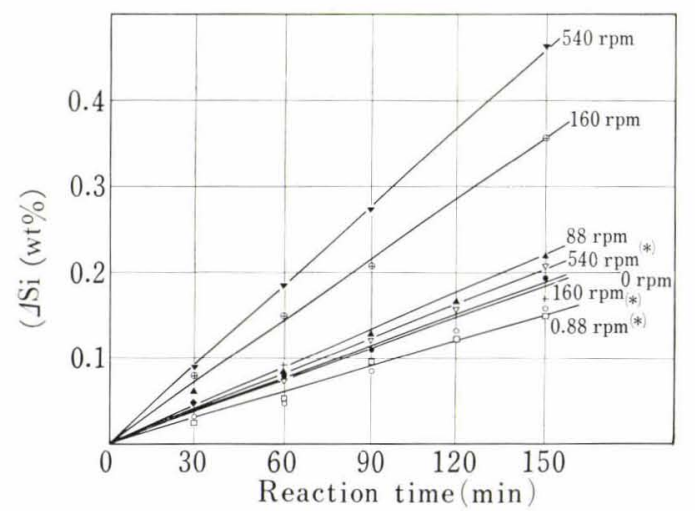

Fig. 2. Influence of stirring speed on the rate of silicon transfer

\begin{tabular}{|c|c|c|c|c|c|c|c|c|c|c|c|c|c|c|c|}
\hline \multirow{2}{*}{\multicolumn{2}{|c|}{ Slag }} & \multicolumn{3}{|c|}{ Composition (wt $\%$ ) } & \multicolumn{5}{|c|}{ 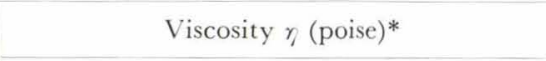 } & \multicolumn{5}{|c|}{ Density $(\mathrm{g} / \mathrm{cc})^{* *}$} & \multirow{2}{*}{$E_{\eta} *(\mathrm{kcal})$} \\
\hline & & $\mathrm{CaO}$ & $\mathrm{SiO}_{2}$ & $\mathrm{Al}_{2} \mathrm{O}_{3}$ & $1450^{\circ} \mathrm{C}$ & $1500^{\circ}$ & $1550^{\circ}$ & $1600^{\circ}$ & $1650^{\circ}$ & $1450^{\circ} \mathrm{C}$ & $1500^{\circ}$ & $1550^{\circ}$ & $1600^{\circ}$ & $1650^{\circ}$ & \\
\hline & Acid & 35 & 50 & 15 & 22.8 & 16.6 & 11.7 & 8.4 & 7.9 & 2.539 & 2.532 & 2.525 & 2.518 & 2.511 & 44 \\
\hline & Basic & 45 & 40 & 15 & 9.0 & 6.0 & 4.5 & 3.2 & 2.3 & 2.608 & 2.601 & 2.594 & 2.587 & 2.580 & 46 \\
\hline \multirow{2}{*}{\multicolumn{7}{|c|}{ Slag composition $(\%)$}} & \multicolumn{6}{|c|}{ Diffusion coeff. $D^{* * *}\left(\mathrm{~cm} / \mathrm{sec}^{2}\right)$} & \multirow{2}{*}{\multicolumn{3}{|c|}{$E_{D}(\mathrm{kcal})$}} \\
\hline & & & & & & & & $1365^{\circ}$ & & & $1430^{\circ} \mathrm{C}$ & & & & \\
\hline \multicolumn{6}{|c|}{$38.5 \mathrm{CaO}-40.5 \mathrm{SiO}_{2}-20.9 \mathrm{Al}_{2} \mathrm{O}_{3}$} & & \multicolumn{3}{|c|}{$4.7 \times 10^{-8}$} & \multicolumn{3}{|c|}{$1.05 \times 10^{-7}$} & \multicolumn{3}{|c|}{70} \\
\hline \multicolumn{16}{|c|}{ Calculated from Reference 6) } \\
\hline$* *$ & \multirow{2}{*}{\multicolumn{15}{|c|}{ * Calculated from Reference 7) }} \\
\hline$* * *$ & & & & & & & & & & & & & & & \\
\hline
\end{tabular}
from slag to metal at $1550^{\circ} \mathrm{C}$ for basic slag-carbon saturated iron system. (*: metal is copper.)

Table 1. Physico-chemical properties of molten $\mathrm{CaO}-\mathrm{SiO}_{2}-\mathrm{Al}_{2} \mathrm{O}_{3}$ slags 
where, $D:$ diffusion coefficient of the reactant $\left(\mathrm{cm} / \mathrm{sec}^{2}\right)$

$\nu$ : kinematic viscosity of the solute $\left(\mathrm{cm}^{2} / \mathrm{sec}\right)$

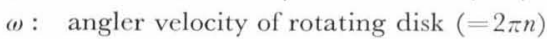

Co: concentration of the reactant in solute $\left(\mathrm{mol} / \mathrm{cm}^{3}\right)$.

Experiment (a)

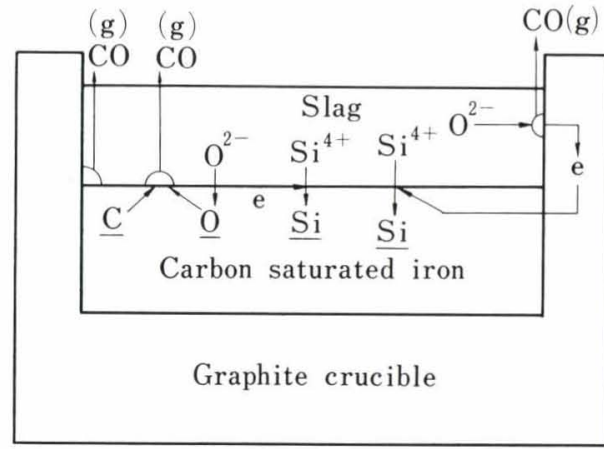

$$
\begin{aligned}
& \left(\mathrm{SiO}_{2}\right)+2 \underline{\mathrm{C}} \stackrel{i_{1}}{\rightarrow} \underline{\mathrm{Si}}+2 \mathrm{CO}(\mathrm{g}) \\
& \left(\mathrm{SiO}_{2}\right)+2 \mathrm{C}(\mathrm{g}) \stackrel{i_{2}}{\rightarrow} \underline{\mathrm{Si}}+2 \mathrm{CO}(\mathrm{g})
\end{aligned}
$$

Experiment (b)

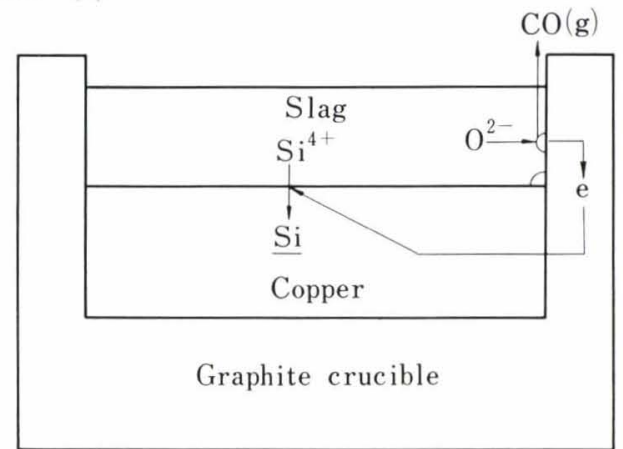

$\left(\mathrm{SiO}_{2}\right)+2 \mathrm{C}(\mathrm{g}) \stackrel{i_{2}}{\rightarrow} \underline{\mathrm{Si}}+2 \mathrm{CO}(\mathrm{g})$

Fig. 3. Schematic illustration of silica reduction in a graphite crucible.
Equation (4) may be applied to the rate equation for the silicon transfer between slag and metal under the following supposition; (1) the stirring is effective only for the slag phase, because the kinematic viscosity of metal is smaller than those of slags, (2) the rate of reaction is controlled by the diffusion steps of reactant, and (3) the stirring is taken place in the region of laminar flow. Since the diffusion coefficient of silicon in slag, $D_{\mathrm{si}}$ and the kinematic viscosity of molten slag, $\nu$ are constant when the reaction temperature and the composition of slag are kept constant, the diffusion flux of silicon, $J_{\mathrm{Si}}$ becomes proportional to the square root of the angular velosity. The relation of $d n_{\mathrm{Si}} / d t$ vs. $(n)^{1 / 2}$ is shown in Fig. 4. In this figure, the lines 1, 2, and 3 represent the results for the acid slag-carbon saturated iron, the basic slag-carbon saturated iron, and the acid and basic slag-copper systems, respectively.

The following equations were derived from the experimental results obtained.

For the slag-carbon saturated iron system,

$$
\begin{aligned}
& d n_{\mathrm{Si}} / d t=6.2+0.335(n)^{1 / 2} \\
& \text { (acid slag) } \\
& d n_{\mathrm{Si}} / d t=2.2+0.140(n)^{1 / 2} \quad \text { (basic slag) } \\
& \left(\times 10^{-4} \mathrm{~mol} / \mathrm{hr} \cdot \mathrm{cm}^{2}\right)
\end{aligned}
$$

and for the slag-copper system,

$$
\begin{array}{r}
d n_{\mathrm{si}} / d t=1.8+0.035(n)^{1 / 2} \quad(\text { acid and basic slag }) \\
\left(\times 10^{-4} \mathrm{~mol} / \mathrm{hr} \cdot \mathrm{cm}^{2}\right) \ldots \ldots \ldots \ldots \ldots . .
\end{array}
$$

\begin{tabular}{|c|c|c|c|c|c|c|c|}
\hline \multicolumn{4}{|c|}{ Carbon saturated iron (experiment A) } & \multicolumn{4}{|c|}{ Copper (experiment B) } \\
\hline Slag & $\begin{array}{l}\text { Temp. } \\
\left({ }^{\circ} \mathrm{C}\right)\end{array}$ & $\begin{array}{l}\text { Stirring speed } \\
(\mathrm{rpm})\end{array}$ & $\begin{array}{c}d n_{\mathrm{Si}} / d t \\
\left(\mathrm{~mol} / \mathrm{hr} \cdot \mathrm{cm}^{2}\right)\end{array}$ & Slag & $\begin{array}{l}\text { Temp. } \\
\left({ }^{\circ} \mathrm{C}\right)\end{array}$ & $\begin{array}{l}\text { Stirring speed } \\
(\mathrm{rpm})\end{array}$ & $\begin{array}{c}d n_{\mathrm{Si}} / d t \\
\left(\mathrm{~mol} / \mathrm{hr} \cdot \mathrm{cm}^{2}\right)\end{array}$ \\
\hline \multirow{8}{*}{ Basic } & 1650 & 0 & $7.51 \times 10^{-4}$ & \multirow{8}{*}{ Basic } & 1650 & 0 & $4.26 \times 10^{-4}$ \\
\hline & & 540 & 11.26 & & & 540 & 2.09 \\
\hline & 1550 & 0 & 2.20 & & 1550 & 0 & 1.80 \\
\hline & & 86 & 2.59 & & & 86 & 1.80 \\
\hline & & 160 & 4.20 & & & 160 & 2.17 \\
\hline & & 540 & 5.36 & & & 540 & 2.45 \\
\hline & 1450 & 0 & 1.14 & & 1450 & 0 & 0.67 \\
\hline & & 540 & 1.47 & & & 540 & 0.40 \\
\hline \multirow{10}{*}{ Acid } & 1650 & 0 & $12.4 \times 10^{-4}$ & \multirow{10}{*}{ Acid } & 1650 & 0 & $6.08 \times 10^{-4}$ \\
\hline & & 530 & 18.0 & & & 535 & 2.94 \\
\hline & 1600 & 0 & 6.84 & & & & \\
\hline & & 535 & 11.4 & & & & \\
\hline & 1550 & 0 & 6.64 & & 1550 & 0 & 1.59 \\
\hline & & 88 & 8.72 & & & 88 & 1.59 \\
\hline & & 157 & 10.44 & & & 157 & 2.10 \\
\hline & & 530 & 14.04 & & & 530 & 2.90 \\
\hline & 1450 & 0 & 2.16 & & 1450 & 0 & 0.31 \\
\hline & & 530 & 2.92 & & & 530 & 0.31 \\
\hline
\end{tabular}

\section{Activation Energy for Overall Reaction}

The rate constant for the overall reaction is plotted as a function of the temperature and is shown in Figs.

Table 2. Rate of silicon transfer from slag to metal 


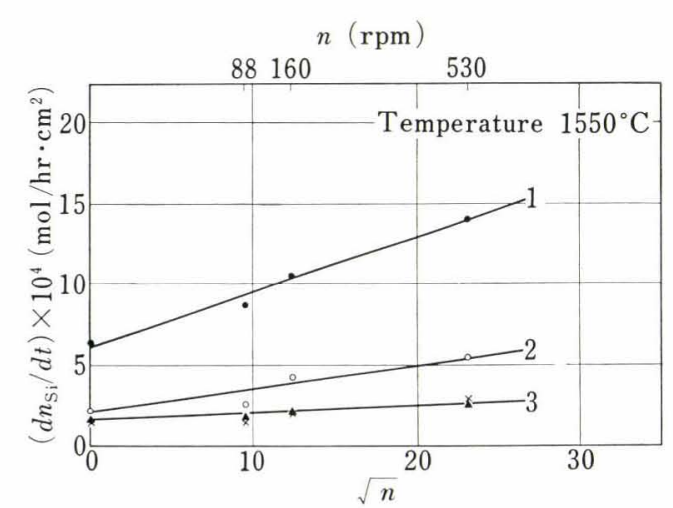

1. Acid slag-carbon saturated iron

2. Basic slag-carbon saturated iron

3. Acid and basic slag-carbon saturated iron

Fig. 4. Relation between the rate of silica reduction and the stirring speed

5(a) and (b) for the basic and acid slags, respectively. These results can well be represented by the Arrhenius type equations. Thus, the activation energies for the overall reaction of silica reduction were calculated from the slopes of the straight lines obtained. When the slag phase was not stirred, the activation energies for the basic and acid slag-carbon saturated iron systems were 64 and $60 \mathrm{kcal} / \mathrm{g} \cdot \mathrm{mol}$, respectively. In the presence of stirring, the activation energies increased to $78 \mathrm{kcal} / \mathrm{g} \cdot \mathrm{mol}$ for the basic slag and 84 for the acid slag. On the other hand, the activation energies for the slag-copper system were 93 and $100 \mathrm{kcal} / \mathrm{g} \cdot \mathrm{mol}$ for the basic and acid slags, respectively. The values of activation energy for the slag-copper system were sufficiently higher than those obtained for the slagcarbon saturated iron system. These results may indicate that there is some discrepancy in the process of silica reduction for the slag-copper and the slagcarbon saturated iron systems.

Influence of the Ratio of Slag-Graphite/Slag-Metal Interfacial Area

Relation between the concentration of silicon in metal and the reaction time at $1550^{\circ} \mathrm{C}$ which is obtained by changing the weight ratio of slag and metal is shown in Fig. 6. In this work, the variations of the weight ratio between slag and metal are corresponding to the ratios of slag-graphite/slag-metal interfacial area of 1.06-4.25 for the basic slag and 1.06-4.35 for the acid slag. The rates of silicon transfer from slag to metal obtained under various experimental conditions are summarized in Table 3. These results show that the influence of the ratio of slag-graphite/ slag-metal interfacial area on the rate of silicon transfer from slag to metal is very small or the rate increases slightly with increasing ratio of the interfacial area.

\section{Mechanism of Silicon Transfer between Slag and Metal}

It is said that the reaction of silicon transfer between slag and metal shows some electrochemical nature. Paying a particular attention to the charge transfer process on the cathode, some experiments on the electrolysis of molten slag were made in order to clarify

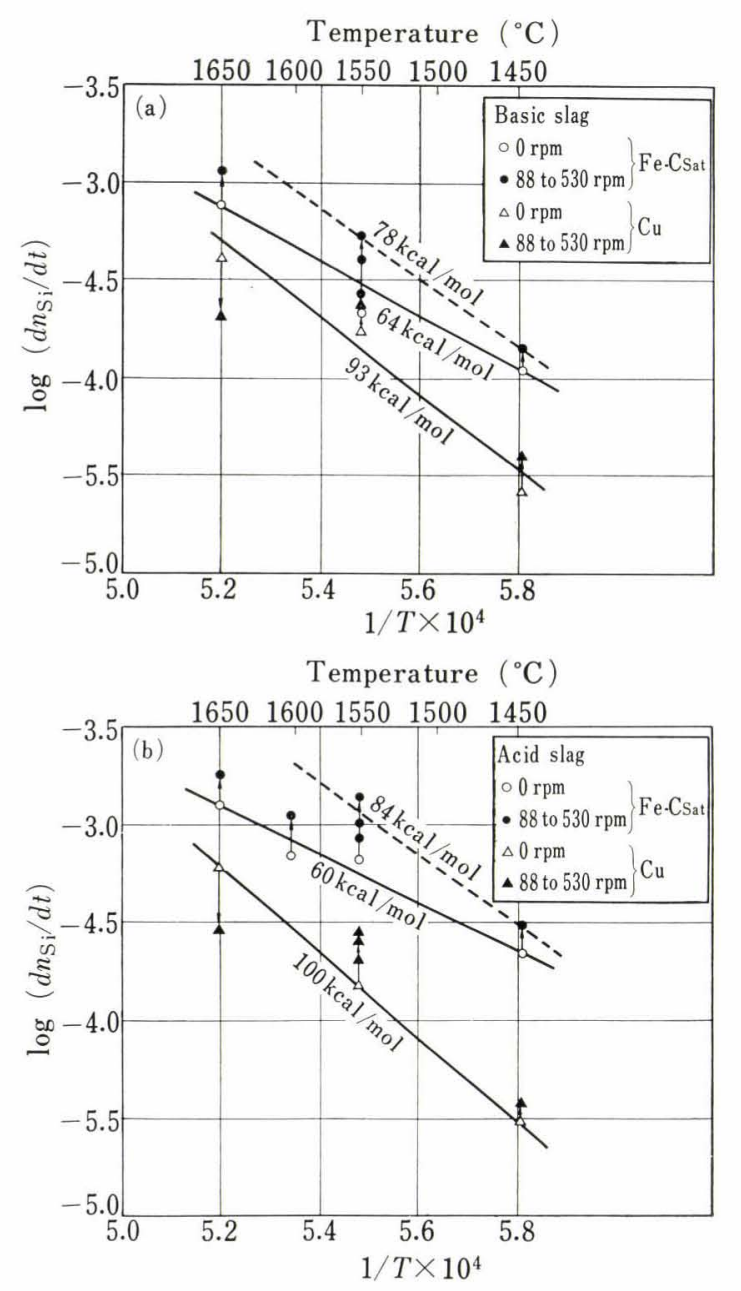

Fig. 5. Arrhenius plots of the rate of silicon transfer from slag to metal

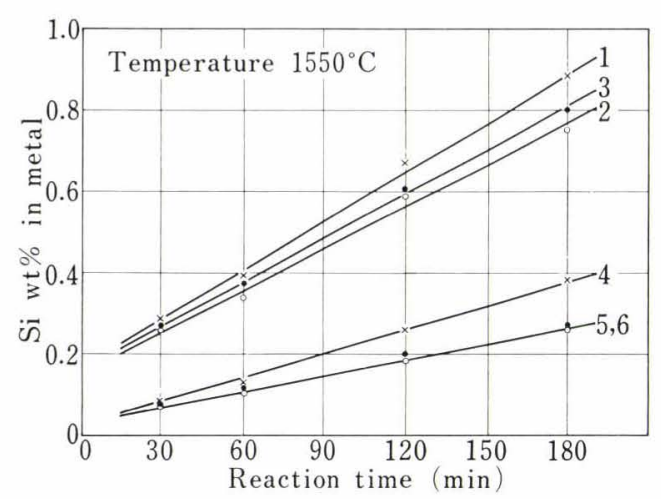

Fig. 6. Rate of silicon transfer from slag to metal in various $\mathrm{slag} / \mathrm{metal}$ weight ratio. (Slag/metal weight ratio: 1. $20 / 20, \quad 2.10 / 20, \quad 3.5 / 20, \quad 4.20 / 20, \quad 5$. $10 / 20$, and 6 . $5 / 20,1,2$, and 3 : acid slag, 4,5 , and 6 : basic slag.)

the mechanism of silicon transfer between slag and metal.

\section{Experimental Procedure}

The apparatus used for the electrolysis of molten slag under the condition of a constant current is schematically shown in Fig. 7(a). The furnace was 


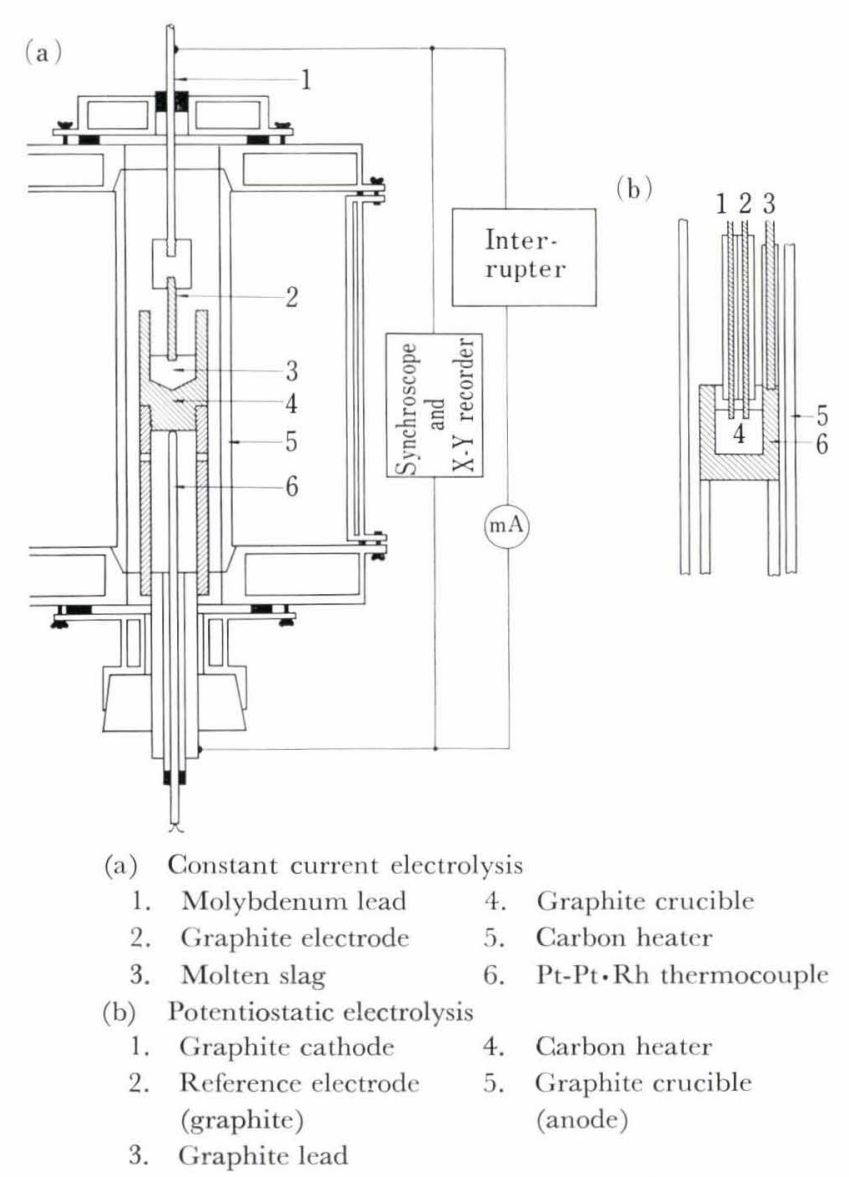

Fig. 7. Apparatus for the electrolysis of molten slags

of a carbon resistance heating type and purified argon gas was used to maintain the furnace atmosphere. The apparatus used may be divided into the following three parts; the electrolytic cell, the circuit for supplying a constant current, and the recorder as an anode and a graphite electrode as a cathode $(6 \mathrm{~mm}$ dia. spectrographic graphite). The circuit for supplying a constant current is made of a dry cell $(200 \mathrm{~V})$ and a variable resistance $(\max$. resistance $20 \mathrm{k} \Omega$ ). Interrupter ${ }^{10)}$ is made of a pulse generater and a mercury wet contact rely. Build up time of the interrupter was less than 1 msec. The electrode potential was recorded by using a synchroscope for rapid variation of the electrode potential, especially for the recording of the build up and the decay curves and a milivolt recorder for the overall potential.

The electrolytic cell used for the potentiostatic electrolysis is shown in Fig. 7(b). The electrode potential was measured between the graphite cathode (3 $\mathrm{mm} \mathrm{dia}$.) and the reference electrode (null current electrode). Depth of the electrode immersed in slag was about $5 \mathrm{~mm}$ dia. Direct current for the electrolysis was supplied by a potentiostat made by Yanagimoto Work Ltd. (voltage of electrolysis $\pm 30 \mathrm{~V}$, max. current $300 \mathrm{~mA}$ ).

\section{Results}

A typical potential-time curve obtained by the constant current electrolysis of acid slag at $1530^{\circ} \mathrm{C}$ is shown in Fig. 8. Potential-jump observed in the time

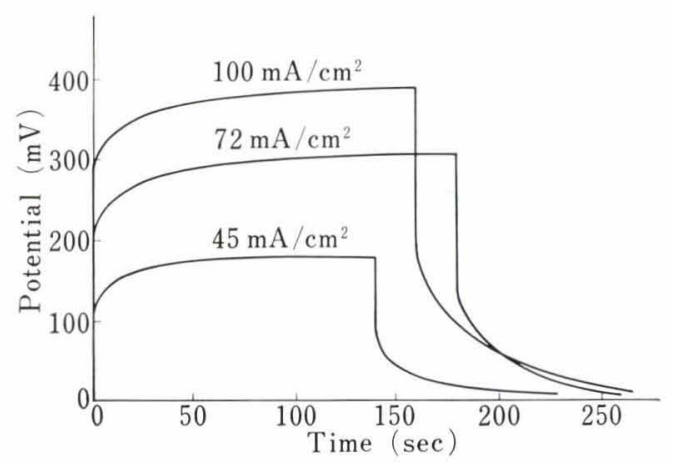

Fig. 8. Typical potential-time curve obtained by the constant current electrolysis

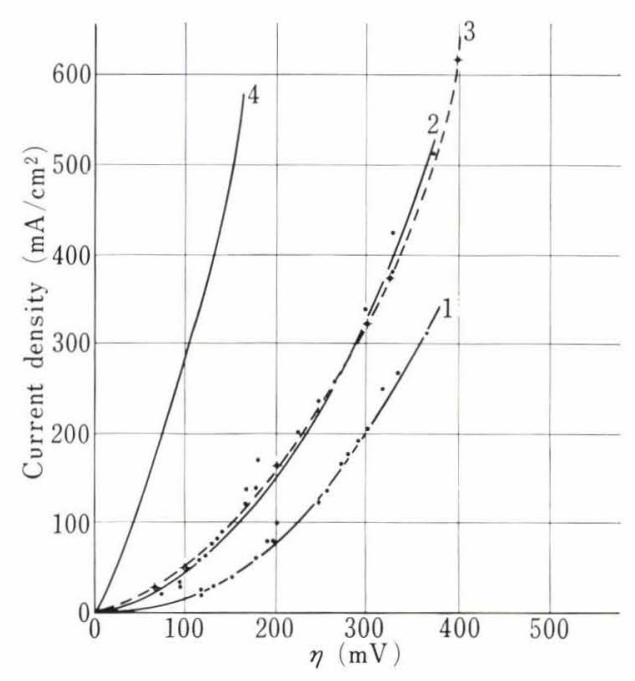

1. Cathodic process for acid slag at $1520^{\circ} \mathrm{C}$

2. Cathodic process for basic slag at $1520^{\circ} \mathrm{C}$

3. Anodic process for $\mathrm{CaO} 40-\mathrm{SiO}_{2} 40-\mathrm{Al}_{2} \mathrm{O}_{3} 20$ slag/ carbon saturated iron at $1520^{\circ} \mathrm{C}^{14)}$

4. Cathodic process for $\mathrm{CaO} 40-\mathrm{SiO}_{2} 40-\mathrm{Al}_{2} \mathrm{O}_{3} 20$ slag/ carbon saturated iron at $1500^{\circ} \mathrm{C}^{4)}$

Fig. 9. Relation between the current density and the overpotential

of switching on is considered to be the resistance overpotential. The potential gradually increases with the lapse of time due to the progress of reaction. When the current is turned off, the resistance overvoltage instantly decreases, but not the reaction overpotential. The time required to attain the constant potential increases with increasing current density.

In order to separate the IR drop from the overall potential precisely, the build up and the decay curve were recorded on the Brown tube of synchroscope by the use of a current interrupter. Photograph 1(a) shows the decay curve for lower current density and Photo. 1(b) for higher current density. The overpotential for the IR drop could be obtained from these photographs. Figure 9 shows the relation between the current density, $i$, and the reaction overpotential, $\eta$. As the references, the results reported by other ivestigators are also shown in this figure.4),14) Curves representing the I- $\eta$ relation obtained in this work satisfied the Tafel's equation (Fig. 10). 

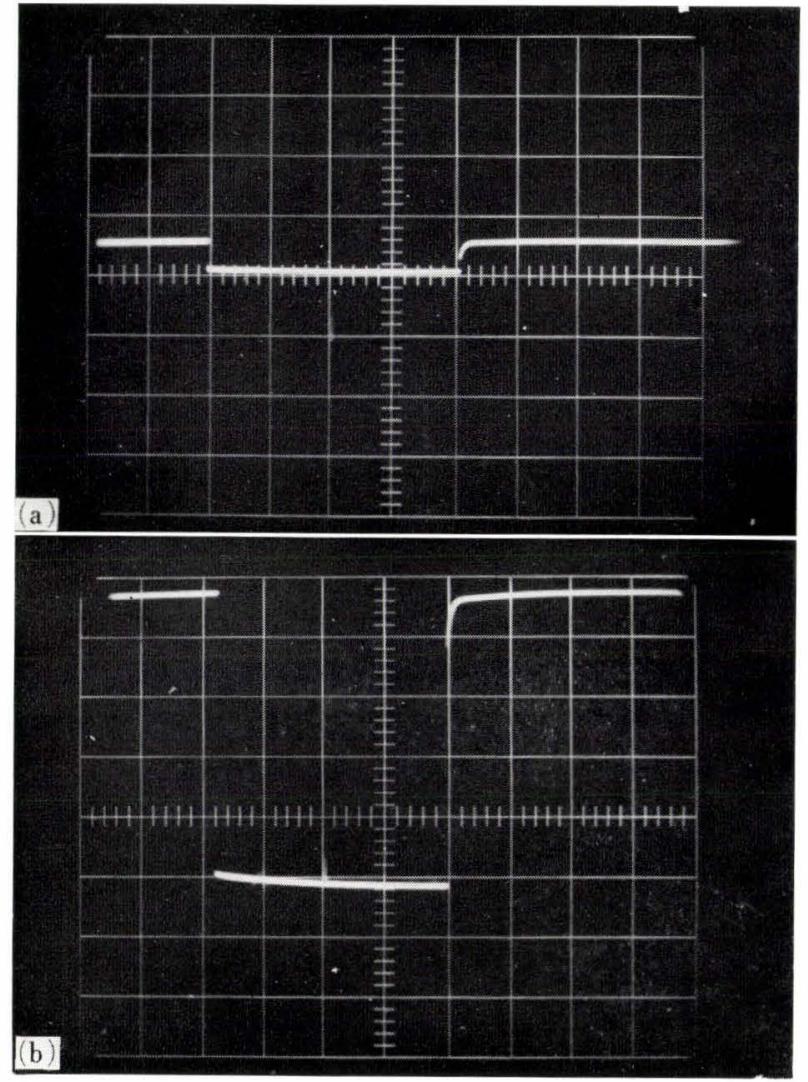

Photo. 1. Typical decay curve for short pulse obtained by the constant current electrolysis

(a) Lower current density

(b) Higher current density

(Ordinate : $0.1 \mathrm{~V} /$ scale div., abscissa : $10 \mathrm{msec} / \mathrm{scale}$ div.)

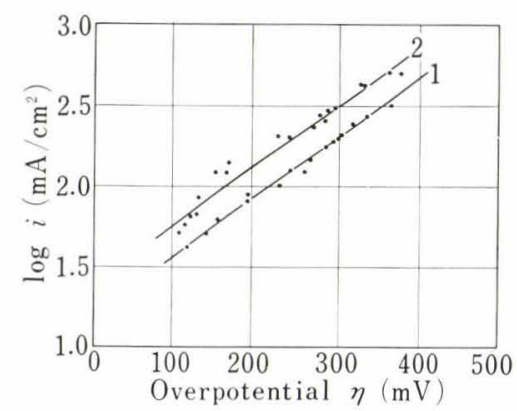

1. Cathodic process for acid slag at $1520^{\circ} \mathrm{C}$

2. Cathodic process for basic slag at $1520^{\circ} \mathrm{C}$

Fig. 10. Tafel's plots for slag-graphite system

In case of the potentiostatic electrolysis of lowsilica containing slag, $\mathrm{CaO}-\mathrm{Al}_{2} \mathrm{O}_{3}-\mathrm{MgO}(50-45-5 \mathrm{wt} \%)$ slag was used as a supporting electrolyte. Figure 11 shows the cathodic polarization curves for the slags containing $\mathrm{FeO}$ and $\mathrm{MnO}$ obtained by the potentiostatic electrolysis at $1420^{\circ} \mathrm{C}$. The polarization curve for the slag containing $\mathrm{FeO}$ shows that there is a limiting current at the potential range of $-(180-400) \mathrm{mV}$. On the other hand, two limiting currents are observed at $-(180-400)$ and $-(400-590) \mathrm{mV}$ in case of the addition of $\mathrm{MnO}$.

Figure 12 shows the cathodic polarization curves for the slags containing 0 to $10 \%$ silica. These curves

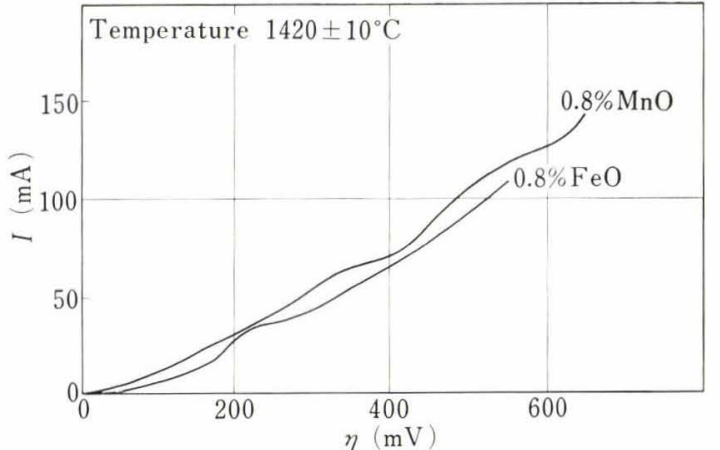

Fig. 11. Relation between $\gamma-1$ for $\mathrm{CaO}-\mathrm{Al}_{2} \mathrm{O}_{3}-\mathrm{MgO}$ slags containing $\mathrm{FeO}$ and $\mathrm{MnO}$

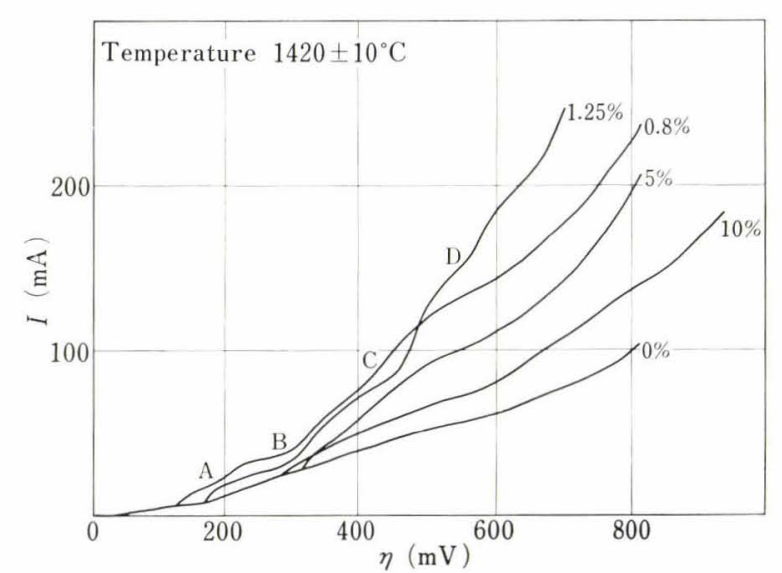

Fig. 12. Potential current curves for $\mathrm{CaO}-\mathrm{Al}_{2} \mathrm{O}_{3}-\mathrm{MgO}$ containing silica

may be divided into three regions ; A-B $-(180-280)$, $\mathrm{B}-\mathrm{C}-(280-430)$, and $\mathrm{C}-\mathrm{D}-(430-540) \mathrm{mV}$, respectively. In A-B region, the reduction of iron oxide may be expected from the fact that the same behaviour is observed for the slag containing $0.8 \% \mathrm{FeO}$ (Fig. 11). As shown in Fig. 12, there are two limiting currents corresponding to two reduction steps of silica for the slag containing low concentration of silica. However, the first and the second steps could not easily be separated for the silica rich slags.

\section{Discussion}

\section{Rate of Silica Reduction}

The rate of silicon transfer from slag to metal may approximately be expressed by the following equation regardless of the stirring action.

$$
d n_{\mathrm{Si}} / d t=k(A / V) C_{\mathrm{SiO}_{2}} \ldots
$$

where, $k:$ specific rate of reaction $(\mathrm{cm} / \mathrm{sec})$

A: interfacial area between slag and metal $\left(\mathrm{cm}^{2}\right)$

$V:$ volume of metal $\left(\mathrm{cm}^{3}\right)$

$C_{\mathrm{SiO}_{2}}$ : concentration of silica in slag $\left(\mathrm{mol} / \mathrm{cm}^{3}\right)$.

The specific rate of reaction, $k$, calculated from Eq. (8) using the values listed in Table 2 was in the range of $10^{-6}$ to $10^{-5} \mathrm{~cm} / \mathrm{sec}$. If the rate of reaction for this system is controlled by the diffusion step in slag, the specific rate, $k_{D}$, can be calculated with 
Eq. (9).

$$
\begin{array}{r}
d n_{\mathrm{Si}} / d t=k_{D}(A / V)\left(C_{\mathrm{SiO}_{2}}-C_{\mathrm{SiO}_{2}}^{*}\right) \\
k_{D}=D_{\mathrm{Si}} / \delta
\end{array}
$$

where, $\quad D_{\mathrm{Si}}$ : diffusion coefficient of silicon in slag

$\tilde{o}:$ thickness of the diffusion layers in slag side

$C_{\mathrm{SiO}_{2}}$ and $C^{*}{ }_{\mathrm{SiO}_{2}}:$ concentrations of silica in the bulk of slag and at the slag-metal interface, respectively.

If the rate of chemical reaction between the slag and metal is sufficiently rapid, $C_{\mathrm{Si}_{2}}^{*}$ is equal to the equilibrium value for the content of silicon observed in metal. On the other hand, the rate of chemical reaction at the interface, $k_{C}$, is expressed as follows;

$$
d n_{\mathrm{si}} / d t=k_{C}(A / V) C_{\mathrm{SiO}_{2}}^{*}
$$

where, $k_{C}$ : rate constant of chemical reaction.

From Eqs. (9) and (11), the following equations can be derived;

$$
\begin{aligned}
d n_{\mathrm{Si}} / d t= & \left(k_{D} k_{C} / k_{D}+k_{C}\right)(A / V) C_{\mathrm{SiO}_{2}} \\
& 1 / k=1 / k_{D}+1 / k_{C} \ldots \ldots \ldots \ldots . . . . .
\end{aligned}
$$

If the values of $D_{\mathrm{Si}}$ and $\delta$ are $10^{-7}$ to $10^{-8} \mathrm{~cm}^{2} / \mathrm{sec}$ and to $10^{-2} \mathrm{~cm}$, respectively, the transport rate of silicon in slag, $k_{D}$, is calculated as $10^{-6}$ to $10^{-5} \mathrm{~cm} / \mathrm{sec}$. This calculated value of $k_{D}$ is nearly equal to the value of the overall specific reaction rate, $k$, obtained in this work. It may therefore be considered that the rate of chemical reaction, $k_{c}$, is very rapid as compared with the rate of diffusion, $k_{D}$, (cf. Eq. (13)) and the rate of overall reaction is controlled by the diffusion of silicon in slag. The activation energies for the silica reduction of basic and acidic slags were 64 and $60 \mathrm{kcal} / \mathrm{g} \cdot \mathrm{mol}$, respectively. According to Riddiford, ${ }^{11)}$ the activation energies for the mass transport due to diffusion $E_{T}$ are given by the following equations,

$$
E_{T}=4 E_{D}+E_{\nu} / 6 \quad \text { (for the laminar flow) }
$$
and

$$
E_{T}=2\left(E_{D}+E_{\nu}\right) / 3 \quad \text { (for the strongly turbulent flow) }
$$

The activation energies for the mass transport calculated from the values listed in Table 1 are 55 (for the laminar flow) and $77 \mathrm{kcal} / \mathrm{g} \cdot \mathrm{mol}$ (for the strongly turbulent flow). From the comparison of the values obtained by the calculation and by the present experiments, it was deduced that the mass transport proceeded nearly in the state of laminar flow.

Based on the results obtained in this experiment, the effect of stirring on the rate of silica reduction could be expressed by the following formula,

$$
d n_{\mathrm{Si}} / d t=a+b \sqrt{n}
$$

where, $a$ and $b$ : constant

$$
n \text { : stirring speed. }
$$

According to Eq. (4), the thickness of the diffusion layer in laminar flow, $\delta$, is expressed as follows,

$$
\begin{aligned}
\quad \delta & =\text { const. } \omega^{-1 / 2} D^{1 / 3} \nu^{-1 / 6} \ldots \ldots \ldots \\
\text { Thus, } \quad k_{t} & =D / \delta=\text { const. } \omega^{1 / 2} D^{2 / 3} \nu^{1 / 6}
\end{aligned}
$$

In comparison between Eqs. (15) and (17), the second term in Eq. (15) may show that the reaction is controlled by the diffusion of reactant. On the other hand, the first term in Eq. (15) may be caused by the thermal convection and the chemical (or the charge transfer) reaction. Similar fact was also observed in the process of sulfur transfer between molten slag and carbon saturated iron. ${ }^{13)}$

\section{Mechanism of Silica Reduction}

As shown in Table 3, variation of the ratio of slag-graphite/slag-metal interfacial area did not give significant effect on the rate of silica reduction. It is therefore considered that the rate of silica reduction by solid graphite is mainly controlled by the cathodic process. If the reduction of silica proceeds electrochemically, it can be distinguished between the anodic and cathodic processes as follows,

in the cathodic process $\left(\mathrm{Si}^{4+}\right)+4 \mathrm{e} \stackrel{i_{c}}{\rightarrow} \underline{\mathrm{Si}}$

in the anodic process $\quad \underline{\mathrm{C}}+\left(\mathrm{O}^{2-}\right) \stackrel{i_{1}}{\rightarrow} \mathrm{CO}(\mathrm{g})+2 \mathrm{e}$

$$
\mathrm{C}(\mathrm{g})+\left(\mathrm{O}^{2-}\right) \stackrel{i_{2}}{\rightarrow} \mathrm{CO}(\mathrm{g})+2 \mathrm{e} .
$$

If the transfer of silicon from slag to metal proceeds

\begin{tabular}{|c|c|c|c|c|c|c|c|}
\hline Slag & $\begin{array}{l}\text { Slag wt (g) } \\
\text { Metal wt (g) }\end{array}$ & $\begin{array}{l}\text { S-G area }\left(\mathrm{cm}^{2}\right) \\
\text { S-M area }\left(\mathrm{cm}^{2}\right)\end{array}$ & $\begin{array}{c}d n_{\mathrm{Si}} / d t \\
\left(\mathrm{~mol} / \mathrm{hr} \cdot \mathrm{cm}^{2}\right)\end{array}$ & Slag & $\begin{array}{l}\text { Slag wt (g) } \\
\text { Metal wt (g) }\end{array}$ & $\begin{array}{l}\text { S-G area }\left(\mathrm{cm}^{2}\right) \\
\text { S-M area }\left(\mathrm{cm}^{2}\right)\end{array}$ & $\begin{array}{c}d n_{\mathrm{Si}} / d t \\
\left(\mathrm{~mol} / \mathrm{hr} \cdot \mathrm{cm}^{2}\right)\end{array}$ \\
\hline \multirow{3}{*}{ Basic } & $\begin{array}{l}20 \\
20\end{array}$ & $\begin{array}{l}14.7 \\
3.46\end{array}$ & $2.80 \times 10^{-4}$ & \multirow{3}{*}{ Acid } & $\begin{array}{l}20 \\
20\end{array}$ & $\frac{15.1}{3.46}$ & $5.45 \times 10^{-4}$ \\
\hline & $\begin{array}{l}10 \\
20\end{array}$ & $\begin{array}{l}7.38 \\
3.46\end{array}$ & $1.79 \times 10^{-4}$ & & $\begin{array}{l}10 \\
20\end{array}$ & $\begin{array}{l}7.52 \\
3.46\end{array}$ & $4.68 \times 10^{-4}$ \\
\hline & $\begin{array}{c}5 \\
20\end{array}$ & $\begin{array}{l}3.68 \\
3.46\end{array}$ & $1.79 \times 10^{-4}$ & & $\begin{array}{c}5 \\
20\end{array}$ & $\begin{array}{l}3.77 \\
3.46\end{array}$ & $4.93 \times 10^{-4}$ \\
\hline
\end{tabular}
by Eqs. (18), (19), and (20), the reaction current across the slag-metal interface can be calculated with the following equation,

$$
d n_{\mathrm{Si}} / d t=i / n F
$$

$$
\begin{aligned}
\text { where, } d n_{S i} / d t: & \text { reaction rate }\left(\mathrm{mol} / \mathrm{sec} \cdot \mathrm{cm}^{2}\right) \\
i: & \text { reaction current }\left(\mathrm{A} / \mathrm{cm}^{2}\right) \\
F: & \text { Faradic constant }(96500 \text { coulomb }) \\
n: & \text { number of charge }(=4, \text { for silicon }) .
\end{aligned}
$$

For the slag-copper system, the reaction of silica reduction proceeds in accordance with reactions (18) and (20), and therefore the cathodic current $i_{c}$ becomes equal to the anodic current $i_{2}$.

Table 3. Rate of silicon transfer from slag to metal in various slag/metal ratio 


$$
i_{c}=i_{2}
$$

For the slag-carbon saturated iron system,

$$
i_{c}=i_{1}+i_{2}
$$

Accordingly, the reaction current for processes (19) and (20) can be calculated from the results listed in Table 2.

Figure 13 shows the relation between the reaction current, $i_{1}$, for reaction (19) and, $i_{2}$, for reaction (20) and the square root of the stirring speed, $n$. The effect of temperature on the ratio of $i_{\mathbf{1}} / i_{2}$ is shown in Fig. 14 . From this figure, it is apparent that the proportion of reaction (20) in the silica reduction increases with increasing temperature.

From the facts mentioned above, it seems that some difference exists between the mechanism of the silica reduction by solid graphite and that by carbon dissolved in metal. When the silica in slag is reduced by carbon saturated iron, it seems that the donation of electron for the cathodic reaction is not only made by the evolution of $\mathrm{CO}$ gas but also by the other anodic

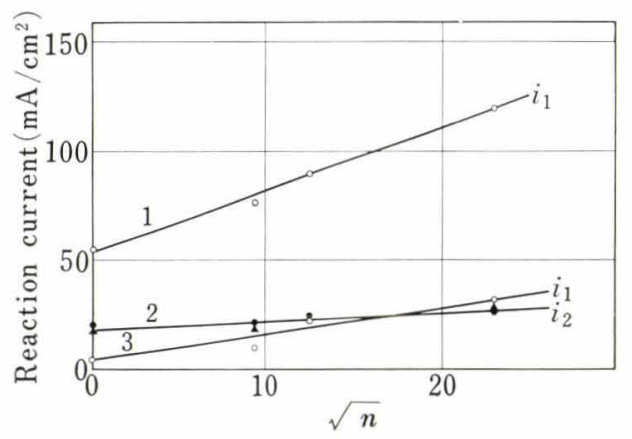

1. Acid slag

2. Basic slag

3. Basic and acid slag

Fig. 13. Relation between the reaction current and the stirring speed at $1550^{\circ} \mathrm{C}$

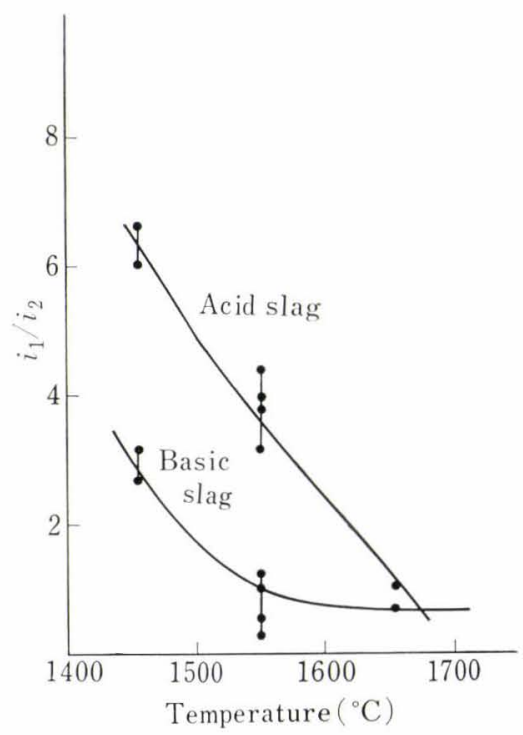

Fig. 14. Temperature dependence of the ratio of anodic reaction current $i_{1} / i_{2}$ reactions such as $\mathrm{Fe} \rightarrow\left(\mathrm{Fe}^{2+}\right)+2$ e. Such a process was observed in the primary stage of silica reduction for the slag-metal system. $\left.{ }^{15}\right)$

As mentioned above, it is considered that the rate of silica reduction is mainly controlled by the cathodic process. In the presence of charge transfer reaction, $\mathrm{O}^{n+}+n e=R$ on the surface of metal, the following equation may be realized between the cathodic overpotential, $\eta_{c}$, and the cathodic current, $i_{c}$.

$$
\begin{array}{r}
i_{c}=i_{f}-i_{b}=i_{o}\left[\exp \left(-\frac{\alpha n E}{R T} \eta_{c}\right)\right. \\
\left.-\exp \left\{\frac{(1-\alpha) n F}{R T} \eta_{c}\right\}\right] \ldots
\end{array}
$$

where, $i_{f}$ : forward reaction current for the charge transfer reaction of $\mathrm{O}^{n+}+n e \rightarrow R$

$i_{b}$ : backward reaction current

$i_{0}$ : exchange current

$\alpha$ : transfer coefficient $(\mathrm{o}<\alpha<1)$.

From the above equation, it is apparent that the first and the second correspond to the forward and the backward reactions of $\mathrm{O}^{n+}+n e=R$, respectively. If the backward reaction is negligibly small, Eq. (24) is simplified as follows,

$$
\begin{aligned}
i_{c}=i_{o} \exp ( & \left.-\frac{\alpha n F}{R T} \eta_{c}\right) \text { or } \eta_{c}=\text { const. } \\
& -\frac{R T}{\alpha n F} \ln i_{c} \ldots \ldots \ldots \ldots \ldots \ldots \ldots \ldots \ldots \ldots
\end{aligned}
$$

Using the results obtained for the constant current electrolysis of $\mathrm{CaO}-\mathrm{SiO}_{2}-\mathrm{Al}_{2} \mathrm{O}_{3}$ slags at $1530^{\circ} \mathrm{C}$ (cf. Fig. 10), the value of $n \alpha$ calculated from Eq. (25) was equal to 1.3. According to the results of the current efficiency for these slags (Fig. 15) ${ }^{16}$, the cathodic reduction of silica in slag proceeds by the following steps,

$$
\mathrm{Si}^{4+}+2 \mathrm{e}=\mathrm{Si}^{2+}
$$

$$
\mathrm{Si}^{2+}+2 \mathrm{e}=\mathrm{Si} \quad \text { (in molten copper cathode)........ }
$$

It was assumed in Fig. 15 that the number of charge, $n$, is equal to 2 . If this assumption is correct,

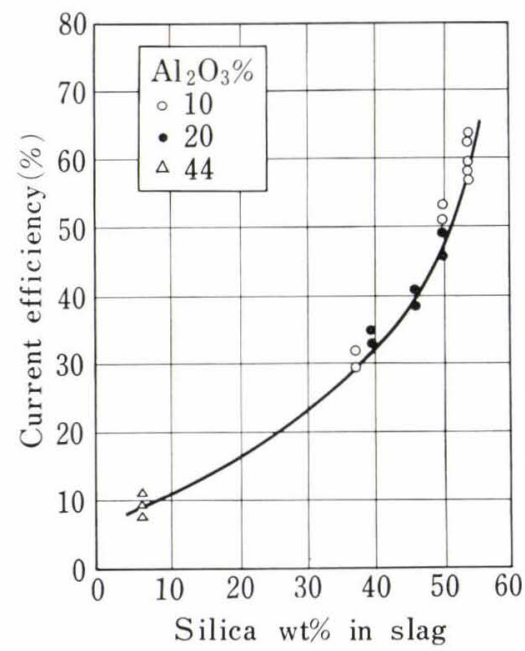

Fig. 15. Current efficiency of $\mathrm{CaO}-\mathrm{SiO}_{2}-\mathrm{Al}_{2} \mathrm{O}_{3}$ slags at $1440^{\circ} \mathrm{C}$ (Adachi and Ogino ${ }^{15}$ ) 
the value of the transfer coefficient, $\alpha$, will be equal to 0.65. This may indicate that the cathodic reaction of silica reduction is nearly reversible.

In order to know the species of the reduced ion, the results obtained for the potentiostatic electrolysis of $\mathrm{CaO}-\mathrm{Al}_{2} \mathrm{O}_{3}-\mathrm{MgO}$ slags containing low concentration of silica (cf. Fig. 12) can be used. The curve shown in Fig. 16, which was obtained by subtracting the curve for $0 \% \mathrm{SiO}_{2}$ from the curve for $1.25 \% \mathrm{SiO}_{2}$ (see Fig. 12), may be regarded as the reducing wave for silica. Applying the formula for the concentration polarization (28), one can obtain $n=2$ for the regions of $\eta=-(280-430) \mathrm{mV}$ and $\eta=-(430-550) \mathrm{mV}$.

$$
\eta=\text { const. }+\frac{R T}{n F} \ln \left(l-\frac{i}{i_{l}}\right)
$$

where, $\eta$ : overpotential

$i$ : cell current

$i_{l}$ : limiting current

$n$ : valency of reduced ion.

The value of valency may be able to correspond to the following two reduction steps of silica in slag,

$$
\begin{array}{r}
\mathrm{Si}^{4+}+2 \mathrm{e} \rightarrow \mathrm{Si}^{2+}\left(\text { first step) and } \mathrm{Si}^{2+}+2 \mathrm{e} \rightarrow \underline{\mathrm{Si}}\right. \\
(\text { second step) } \ldots \ldots \ldots \ldots \ldots \ldots \ldots \ldots \ldots \ldots \ldots
\end{array}
$$

For the silica-rich slags, the second step disappeared. It may be caused by the backward reaction (29) resulting from the stability of $\mathrm{Si}^{2+}$ ion in the slags. $\left.{ }^{17}\right)$

$$
\underline{\mathrm{Si}}+\mathrm{Si}^{4+} \rightarrow 2 \mathrm{Si}^{2+}
$$

Using the result obtained for the slag containing $1.25 \% \mathrm{SiO}_{2}$, the thickness of the diffusion layer, $\delta$, was calculated from Eq. (28).

$$
\delta=n F D_{\mathrm{Si}} C_{\mathrm{S} i}^{*} / i_{l}
$$

where, $D_{\mathrm{Si}}$ : diffusion coefficient of silica in slag (about $10^{-7} \mathrm{~cm}^{2}$ sec)

$C^{*}{ }_{\mathrm{Si}}:$ concentration of silicon in slag $\left(1.1 \times 10^{-3} \mathrm{~mol} / \mathrm{cm}^{3}\right)$

$i_{1}$ : limiting current density $\left(0.006 \mathrm{~A} / \mathrm{cm}^{2}\right.$ for the first step and $0.25 \mathrm{~A} / \mathrm{cm}^{2}$ for the second step).

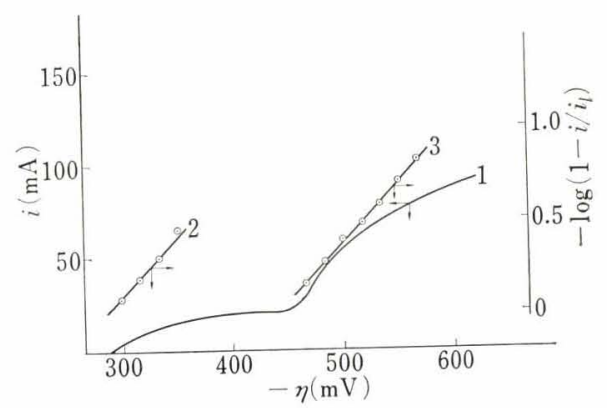

Fig. 16. Cathodic polarization curve of silica in moten slag at $1420^{\circ} \mathrm{C}$
The calculated values of the thickness of the diffusion layer for the first and second steps were $3.4 \times 10^{-4}$ and $8 \times 10^{-5} \mathrm{~cm}$, respectively. These values are considered reasonable for the metallurgical process at high temperature.

\section{Summary}

Some experiments were made to know the rate and the mechanism of silica reduction and the results are summarized as follows.

(1) The rate of silica reduction increased by the stirring of the slag phase and the increased rate of reaction was proportional to the square root of the stirring speed.

(2) This may show that the rate of silica reduction is mainly controlled by the diffusion of silicon in slag.

(3) The effect of the ratio of slag-graphite/slagmetal interfacial area on the reaction rate was relatively small in this experiment.

(4) Reduction of silica in slag may proceed by the following two step process; $\mathrm{Si}^{4+} \rightarrow \mathrm{Si}^{2+} \rightarrow \mathrm{Si}$.

(5) There may be some difference in the mechanisms of silica reduction by solid graphite and by carbon dissolved in metal.

\section{REFERENCES}

1) J. C. Fulton and J. Chipman: Trans. Met. Soc. AIME, 215 (1959), 888.

2) J. R. Ralling and J. F. Elliot: Trans. Met. Soc. AIME, 233 (1965), 1539.

3) E. T. Turkdogan, P. Grieveson, and J. F. Beisler: Trans. Met. Soc. AIME, 227 (1963), 1265.

4) A. I. Sotnikov, O. A. Esin, L. N. Barmin, and A. A. Plyshevskii : Izvest. VUZ. Chernaya Met., (1967) No. 7, 5.

5) M. Grimble, R. G. Ward and D. J. Williams: J. Iron Steel Inst., 203 (1965), 264.

6) P. Kozakevitch : Physical Chemistry of Process Metallurgy Part 1, (1961), 97,

7) R. Kammel and H. Winterhager: Arch. Erzmetallhuttenw., 18 (1965), Heft 1, 9.

8) C. Yoshii and T. Tanimura: Tetsu-to-Hagané, 51 (1965), 883, and 1823.

9) V. G. Levich: Physicochemical Hydrodynamics, (1962), Prentice Hall, New York.

10) T. Hayashi, Y. Kuwa, M. Yoshida, and N. Kikumoto: Denki-Kagaku, 33 (1964), 584.

11) A. C. Riddiford: J. Phys. Chem., 56 (1952), 746.

12) H. Towers and J. Chipman: Trans. Met. Soc. AIME, 209 (1957), 769

13) V. A. Grigoryan: Fizikokimii. Osnov. Proizvo. Stali, (1964), 249, Nauka, Mockva.

14) P. I. Buelv, O. A. Esin and Yu. P. Nikitin: Elektrokhimiya, 3 (1967), 288.

15) M. Ashizuka, M. Tokuda, and M. Ohtani : Tetsu-to-Hagané, 52 (1966), 23.

16) A. Adachi and K. Ogino: Denki-Kagaku, 32 (1964), 145.

17) O. A. Esin: Tr. Tchetvertogo Soveshchaniya po Elektrokhimii, (1959), 311. 